\title{
TEKNIK PEMBESARAN IKAN NILEM (Osteochilus hasselti) DI BALAI PENGEMBANGAN DAN PEMACUAN STOK IKAN GURAME DAN NILEM (BPPSIGN) TASIKMALAYA, JAWA BARAT
}

\section{The Grow out of nilem fish (Osteochilus hasselti) In "Balai Pengembangan dan Pemacuan Stok Ikan Gurame dan Nilem (BPPSIGN) Tasikmalaya, Jawa Barat"}

\author{
Aulia Ikhsan Syamsuri ${ }^{1}$, M. Wahyu Alfian ${ }^{1}$, Vivaldy Phaza Muharta ${ }^{1}$, Akhmad Taufiq Mukti ${ }^{2}$, \\ Kismiyati $^{2}$ dan Woro Hastuti Satyantini ${ }^{2}$. \\ ${ }^{1}$ Program Studi Budidaya Perairan, Fakultas Perikanan dan Kelautan, Universitas Airlangga, Surabaya \\ ${ }^{2}$ Departemen Manajemen Kesehatan Ikan dan Budidaya Perairan, Fakultas Perikanan dan Kelautan, Universitas \\ Airlangga, Surabaya \\ *aulia.ikhsan.syamsuri-2014@fpk.unair.ac.id
}

\begin{abstract}
Abstrak
Ikan nilem (Osteochilus hasselti) merupakan salah satu ikan endemik Indonesia khususnya daerah Jawa Barat yang hidup di perairan tawar. Ikan nilem memiliki ciri yang hampir serupa dengan ikan mas, dikarenakan ikan tersebut masih satu famili dengan ikan mas. Keunggulan dari ikan nilem bukan hanya dari hal gizi, namun juga dikarenakan harga ikan yang sangat terjangkau bagi masyarakat dan ikan ini sangat digemari oleh masyarakat di daerah Jawa Barat. Praktek Kerja Lapang ini dilaksanakan di Balai Pengembangan dan Pemacuan Stok Ikan Gurame dan Nilem Tasikmalaya, Jawa Barat pada tanggal 23 Januari sampai 23 Februari 2017. Metode kerja yang digunakan dalam Praktek Kerja Lapang adalah dengan cara mengikuti langsung kegiatan pembesaran ikan nilem dimulai dari persiapan kolam, penyediaan air budidaya, sumber air yang dipakai dan penebaran benih ikan nilem di Balai Pengembangan dan Pemacuan Stok Ikan Gurame dan Nilem Tasikmalaya, Jawa Barat. Hasil Praktek Kerja Lapang tentang teknik pembesaran ikan nilem adalah dimulai dari persiapan kolam, pada bagian kolam dilakukan pembersihan kolam, pembalikan tanah, pengeringan kolam yang dilakukan selama $5-7$ hari, selanjutnya dilakukan penggaraman dan pengapuran dengan perbandingan 1:1 serta dosis masing-masing 75-100 gram $/ \mathrm{m}^{2}$ dan dibiarkan selama 5 hari. Selanjutnya, air dialirkan dari bak filter ke kolam sampai ketinggian 100-120 cm. Penebaran benih ikan nilem dilakukan pada pagi hari untuk menghindari stress ikan. Benih ikan diperoleh dari balai itu sendiri, dengan ukuran 5-6 cm pada fase pendederan ketiga. Pakan diberikan sebanyak dua kali sehari yaitu pada waktu pagi dan sore hari dengan dosis masing-masing 1,45 $\mathrm{kg} /$ pemberian. Sumber air yang digunakan pada kolam pembesaran ikan nilem berasal dari saluran irigasi sungai Cipakat dan sumur bor digunakan pada musim kemarau. Parameter kualitas air diukur setiap satu minggu sekali. Suhu rata-rata untuk ikan nilem antara $23,14^{\circ} \mathrm{C}-27,73^{\circ} \mathrm{C}$, pH rata-rata 6,22 dan DO rata-rata 5,45 mg/l. Pada saat praktek kerja lapang tidak dilakukan pergantian air kolam dikarenakan, kondisi bahan organik tergolong tidak berlebihan, sehingga tidak mengakibatkan kematian pada ikan. Hal tersebut disebabkan kepadatan ikan yang dipelihara tidak tinggi dalam satu kolam. Pencegahan hama dan penyakit ikan nilem dilakukan dengan pemberian tanaman babadotan (Ageratum conyzoides) dan jarong (Achyranthes aspera) pada proses persiapan kolam serta pemberian daun sente (Alocasia macrorrhiza) dan daun singkong (Manihot esculenta) pada saat terjadi kematian mendadak.
\end{abstract}

Kata kunci: Teknik Pembesaran, Ikan Nilem dan Osteochilus hasselti

\begin{abstract}
Nilem (Osteochilus hasselti) is one of endemic fish Indonesia especially at West Java region living in fresh water. Nilem having a similar to the carp, because the fish still in the same family to the carp. The advantage of nilem not only of the nutrition, but also because of price is very affordable and very popular by the community in West Java. Field Work Practice was held in the "Balai Pengembangan dan Pemacuan Stok Ikan Gurame dan Nilem (BPPSIGN) Tasikmalaya, Jawa Barat" on January 23th , until February 23th, 2017. The working method used in the Field Work Practice is by following the nilem fish enlargement activity starting from the preparation of ponds, the provision of aquaculture water, the source of the water used and the stocking of nilem seeds in the "Balai Pengembangan dan Pemacuan Stok Ikan Gurame dan Nilem (BPPSIGN) Tasikmalaya, Jawa Barat". The results of the field work practices on the grow out technique of nilem fish is started from the preparation of ponds, the pond condition must cleaned, soil reversal, pond drying for 5 - 7 days, then do salting and liming with a ratio of 1: 1 and each dose of 75-100 gram / $\mathrm{m} 2$ and left for 5 days.
\end{abstract}


Furthermore, water is flowed from the filter basin to the pond until the height of $100-120 \mathrm{~cm}$. Restocking done in the morning to avoid stress fish. The fish seed are obtained from own hatchery, within a size of 5-6 $\mathrm{cm}$ in the phase of the third nursery. Feed is given twice daily, in the morning and sick days with a dose of $1.45 \mathrm{~kg}$ each time. The water source that used on enlargement nilem pond derived from the Cipakat river irrigation channel and when entering the dry season using wellbore. The water quality parameters measured every once a week. The average temperature for nilem between $23,14^{0} \mathrm{C}-27,73^{\circ} \mathrm{C}$, the average $\mathrm{pH}$ is 6.22 and the average DO is $5.45 \mathrm{mg} / 1$. At the field work practice we are not to do the water replacement of pond because, the condition of organic matter sorted not excessive, so can not be mortality in fish. This is because the density of fish is not fully effective in pond. Pests and diseases prevention of nilem are done by the provision of babadotan plants (Ageratum conyzoides) and jarong (Achyranthes aspera) in the preparation of the pond and the provision of sente leaves (Alocasia macrorrhiza) and cassava leaves (Manihot esculenta) at the time of sudden death.

Keywords: Enlargement Technique, Nilem Fish and Osteochilus hasselti

\section{PENDAHULUAN}

Budidaya ikan di Indonesia merupakan salah satu komponen yang penting pada sektor perikanan. Hal ini berkaitan dengan perannya dalam menunjang ketersediaan pangan nasional, menciptakan pendapatan dan lapangan kerja. Budidaya ikan juga berperan dalam upaya mengurangi beban sumber daya laut. Selain itu, budidaya ikan dianggap sebagai sektor penting untuk mendukung perkembangan ekonomi pedesaan. Salah satu budidaya ikan yang dikembangkan saat ini adalah budidaya ikan nilem.

Ikan nilem (Osteochilus hasselti) merupakan ikan endemik (asli) Indonesia yang hidup di perairan tawar, seperti sungai dan rawa-rawa. Ciri-ciri ikan nilem hampir serupa dengan ikan mas, yaitu pada sudut mulutnya terdapat dua pasang sungut yang berfungsi sebagai indera peraba. Ujung mulut berbentuk runcing dengan moncong (rostral) terlipat. Ikan ini cukup digemari karena rasa dagingnya yang enak, kenyal dan gurih dan durinya tidak terlalu banyak dibandingkan dengan ikan tawes (Mulyasari et al., 2010).

Budidaya ikan nilem memiliki keuntungan baik dalam sisi ekonomi dan kelestarian lingkungan. Ikan ini termasuk ikan bernilai ekonomis. Disisi harga, ikan nilem sangat terjangkau bagi masyarakat dan ikan ini sangat digemari khususnya di daerah Jawa Barat. Ikan nilem merupakan ikan yang memakan ganggang sehingga ikan ini tergolong ikan herbivora. Keuntungan lainnya dilihat dari aspek kelestarian lingkungan, komoditas ini bisa berperan sebagai pembersih kotoran karena kebiasaan makannya (Subagja et al., 2007). Kebiasaan makan ikan nilem yaitu memakan lumut ataupun ganggang yang menempel pada dinding perairan. Keberadaan populasi ikan nilem di perairan umum semakin menurun. Penurunan populasi ikan nilem karena eksploitasi dan akibat dari perubahan lingkungan perairan. Oleh karena itu, perlu adanya teknik pembesaran ikan nilem agar dapat meningkatkan populasi dan menjamin kelestarian ikan nilem. Teknik pembesaran ikan nilem biasanya dimulai dari benih sampai ukuran siap untuk dikonsumsi (Subagja et al., 2007). Salah satu Balai yang membudidayakan ikan nilem yaitu Balai Pengembangan dan Pemacuan Stok Ikan Gurame dan Nilem (BPPSIGN) Tasikmalaya. Tujuan pelaksanaan Praktek Kerja Lapang (PKL) ini adalah untuk mengetahui teknik pembesaran ikan nilem di Balai Pengembangan dan Pemacuan Stok Ikan Gurame dan Nilem Tasikmalaya, serta masalah dan prospek usaha pembesaran ikan nilem.

\section{METODOLOGI Waktu dan Tempat}

Kegiatan Praktek Kerja Lapang (PKL) Praktek Kerja Lapang ini dilaksanakan di Balai Pengembangan dan Pemacuan Stok Ikan Gurame dan Nilem, Tasikmalaya, Jawa Barat. Kegiatan Praktek Kerja Lapang ini dilaksanakan mulai tanggal 23 Januari - 23 Februari 2017. 


\section{Metode Penelitian}

Metode kerja yang digunakan dalam Praktek Kerja Lapang ini adalah dengan mengikuti secara langsung kegiatan pembesaran ikan nilem di Balai Pengembangan dan Pemacuan Stok Ikan Gurame dan Nilem (BPPSIGN) dan laporan Praktek Kerja Lapang ditulis dengan metode deskriptif, dengan membandingkan antara data dari literatur dengan data dari lapangan.

\section{HASIL DAN PEMBAHASAN}

Balai Pengembangan dan Pemacuan Stok Ikan Gurame dan Nilem (BPPSIGN) Tasikmalaya dibentuk berdasarkan pada Peraturan Gubernur Jawa Barat Nomor 59 Tahun 2014 tentang Organisasi dan Tata Kerja Unit Pelaksana Teknis Dinas dan Badan di Lingkungan Pemerintah Provinsi Jawa Barat. Adapun tugas pokok Balai Pengembangan Budidaya Ikan Gurame dan Nilem Tasikmalaya berdasarkan Peraturan Gubernur Jawa Barat Nomor 37 Tahun 2015 adalah menyelenggarakan pengkajian bahan kebijakan teknis bidang pengembangan budidaya ikan Gurame dan Nilem, menyelenggarakan sebagian tugas teknis operasional Dinas yang merupakan urusan Pemerintahan Daerah Provinsi di bidang perikanan dan kelautan meliputi aspek teknis pengembangan budidaya ikan Gurame dan Nilem serta menyelenggarakan pelayanan administrasi dan pelayanan publik sesuai tugas pokok dan fungsi Balai.

\section{Kegiatan Teknik Pembesaran Ikan Nilem}

Kegiatan teknik pembesaran ikan nilem meliputi perbaikan konstruksi kolam pembesaran ikan nilem, persiapan kolam, penyediaan air budidaya, sumber air yang dipakai dan padat penebaran ikan nilem. Pertumbuhan ikan nilem dimulai dari fase pendederan sampai pembesaran. Pada fase pendederan terbagi menjadi tiga tahap yaitu pendederan
1 - pendederan 3. Sedangkan pada fase pembesaran terbagai menjadi dua tahap yaitu fase pembesaran tahap 1 dan fase pembesaran tahap 2 .

\section{Persiapan Kolam}

Tahapan persiapan kolam terdiri dari beberapa hal yang harus dilakukan yaitu dimulai dari pembersihan kolam, pembalikan tanah, pengeringan, pengapuran menggunakan kapur $\mathrm{CaO}$ dengan dosis $75-150$ gram $/ \mathrm{m}^{2}$ dan penggaraman menggunakan garam krosok dengan dosis 75-150 gram $/ \mathrm{m}^{2}$ kemudian dibiarkan selama 5 hari. Pengisian air merupakan yang wajib dilakukan karena air merupakan media ikan nilem.

\section{Penyediaan Air Budidaya}

Penyediaan air budidaya pada kolam pembesaran ikan nilem berasal dari bak filter (ukuran $8 \mathrm{~m}^{2}$ ) yang telah diberi saringan stainless steel dengan ukuran net kurang lebih $1000 \mu \mathrm{m}$. Kemudian air mulai dialirkan pada kolam dengan cara membuka pintu masuk air (inlet). Pengisian air kolam pembesaran ikan nilem dilakukan sampai ketinggian $100-120 \mathrm{~cm}$. Sumber air yang digunakan pada kolam pembesaran ikan nilem berasal dari saluran irigasi sungai Cipakat dan sumur bor. Sumber air utama yang digunakan untuk pembesaran ikan nilem ialah saluran irigasi sungai Cipakat.

\section{Manajemen Pakan}

Manajemen pakan pada teknik pembesaran ikan nilem di Balai Pengembangan dan Pemacuan Stok Ikan Gurame dan Nilem (BPPSIGN) meliputi, jenis pakan yang digunakan, teknik pemberian pakan, frekuensi dosis pakan yang diberikan, dan penyediaan pakan.

Jenis pakan yang digunakan untuk pembesaran ikan nilem di Balai Pengembangan dan Pemacuan Stok Ikan Gurame dan Nilem (BPPSIGN) adalah pakan buatan dengan jenis pellet yang bersifat mengapung dan memiliki kandungan protein $31-33 \%$, lemak $3-5 \%$, serat 4 - 
6\%, kadar abu 10 - 13\% dan kadar air 11 - 13\%. Jumlah pakan yang diberikan sesuai dengan jumlah dan ukuran ikan. Dosis pakan yang diberikan untuk pembesaran ikan nilem ialah $3-5 \%$ dari jumlah berat total ikan perharinya pada lama pemeliharaan 180 hari. Frekuensi pemberian pakan dilakukan dua kali sehari yaitu pagi hari jam 07.30 WIB dan sore hari jam 15.30 WIB, dimana dalam satu hari menghabiskan pakan sekitar 2,9 $\mathrm{kg} / \mathrm{kolam}$ dengan pemberian pakan sebanyak $1,45 \mathrm{~kg} /$ pemberian. Setiap pemberian pakan dilakukan menggunakan tangan dengan cara pakan disebar merata di pinggir kolam dengan empat titik pemberian yang berbeda.

\section{Monitoring Kualitas Air}

Beberapa faktor yang mempengaruhi kualitas air selama pembesaran ikan nilem pada saat Praktek Kerja Lapang antara lain suhu, derajat keasaman $(\mathrm{pH})$ dan oksigen terlarut (DO). Pengamatan kualitas air dilakukan setiap hari sekali terutama pengukuran suhu dilakukan pada pukul 06.00 pagi, pukul 13.00 siang dan pukul 16.00 sore. Hal ini dilakukan karena pada waktu tersebut merupakaan keadaan ekstrim yang dapat menyebabkan terjadinya kenaikan ataupun penurunan kualitas air secara drastis, sehingga diperlukan pengukuran untuk mengetahui batas suhu, $\mathrm{pH}$ dan $\mathrm{DO}$ yang dapat ditolerir oleh ikan nilem.

Hasil pengukuran suhu di kolam pembesaran adalah $22-28^{\circ} \mathrm{C}$ kisaran ini masih layak untuk pemeliharaan ikan nilem dikarenakan menurut Simanjuntak (2010) menyatakan bahwa, suhu air optimum untuk ikan nilem berkisar $18-28^{\circ}$ C. Pengukuran $\mathrm{pH}$ dilakukan dengan menggunakan $\mathrm{pH}$ paper. Nilai $\mathrm{pH}$ pada kolam pembesaran ikan nilem di BPPSIGN, Tasikmalaya sebesar 6,22. Menurut Wicaksono (2005) menyatakan bahwa, pH optimum untuk perairan berkisar antara 6,5 - 9. Hasil yang diperoleh dari pengukuran oksigen terlarut berkisar 5,2 - 5,7 mg/l. Menurut
Wijayanti et al., (1995) menyatakan bahwa, oksigen terlarut untuk ikan nilem berkisar antara $5-7 \mathrm{mg} / \mathrm{l}$.

\section{Teknik Pemanenan dan Pemasaran Ikan}

Waktu panen dilakukan ketika suhu tidak terlalu tinggi atau ketika sinar matahari tidak terik, biasanya waktu yang tepat adalah pagi hari (05.00 - 08.00) atau sore hari (15.00 - 18.00). Umur ikan yang di panen tergantung dari permintaan pasar. Untuk ukuran konsumsi biasanya ikan berumur 5 - 6 bulan masa pembesaran dengan berat mencapai 100 gram. Proses pemanenan diawali dengan cara mengurangi volume air kolam, pada pintu outlet diberi saringan halus agar ikan tidak keluar kolam. Selanjutnya menunggu air kolam hampir surut, kemudian ikan nilem secara alamiah mengikuti arus air melalui parit yang mengarah ke kubangan dan siap dipanen. Wilayah pemasaran ikan nilem masih seputar Tasikmalaya atau wilayah Jawa Barat. Biasanya konsumen atau pembeli secara langsung datang ke Balai BPPSIGN untuk membeli ikan nilem. Pada proses pemasaran kegiatan pengemasan sangat penting dilakukan agar ikan tetap hidup. Transportasi memiliki dua metode yaitu metode tertutup dan metode terbuka. Metode tertutup ialah metode transportasi ikan hidup dengan menggunakan tempat atau wadah tertutup sedangkan metode terbuka adalah metode transportasi ikan hidup yang diangkut dengan wadah atau tempat yang menggunakan air yang masih dapat berhubungan dengan udara bebas.

\section{Hama dan Penyakit Ikan}

Hama adalah organisme yang bersifat kompetitor yang dapat merusak dan menganggu perkembangan suatu organisme dalam suatu populasi. Hama yang menyerang kolam pembesaran ikan nilem di BPPSIGN, Tasikmalaya adalah ular, ikan betok, ikan gabus, ikan nila dan katak. Pengamatan penyakit ikan nilem 
dilakukan di laboratorium BPPSIGN, Tasikmalaya. Hasil pengamatan yang telah dilakukan didapatkan adanya parasit yang menyerang ikan nilem disebabkan oleh penyakit infectious. Gejala ikan yang mengalami penyakit infectious terdapat bintik-bintik putih, nekrosis pada bagian insang dan terdapat lendir berlebih di tubuh ikan. Berdasarkan gejala klinis tersebut menurut Komarudin dkk, (1991) dapat disebabkan oleh parasit Ichthyophthirius, dikarenakan parasit tersebut menyerang pada bagian kulit dan insang pada ikan. Gejala ikan yang mengalami penyakit non infectious, ikan lebih sering berada di atas permukaan air, lemas dan sukar bergerak.

\section{Pencegahan dan Penanggulangan Hama dan Penyakit}

Pencegahan dan penanggulangan hama pada ikan nilem di BPPSIGN, Tasikmalaya adalah dengan pembuatan pagar dan kawat di pematang kolam budidaya, mengoptimalkan biosecurity, penyemprotan pestisida seperti saponin dengan dosis $0,5-5 \mathrm{ml} / \mathrm{m}^{2}$ saat persiapan kolam. Penanggulangan penyakit pada Balai BPPSIGN dengan pemberian jarong dan babadotan yang merupakan sejenis rumput liar dan diberikan garam sesuai dosis yang dibutuhkan pada proses persiapan kolam. Apabila dalam proses kegiatan pembesaran ikan nilem terjadi kematian mendadak dilakukan pemberian daun sente (Alocasia sp.) dan daun singkong (Manihot esculenta) secukupnya.

\section{Analisa Usaha}

Analisa usaha dalam bidang perikanan dilakukan untuk mengetahui keuntungan yang diperoleh dari usaha perikanan dalam satu siklus produksi. Dengan adanya analisa usaha dapat dibuat perhitungan jangka panjang dalam menentukan tindakan atau memperbaiki dan meningkatkan keuntungan budidaya, sehingga usaha yang dilakukan tersebut layak atau tidak untuk dikembangkan. Secara garis besar, pelaku usaha perika- nan dapat mengetahui penerimaan dan keuntungan yang diperoleh serta berapa lama kemungkinan modal dapat kembali.

Pembesaran ikan nilem merupakan usaha yang memiliki prospek yang baik, karena keuntungan yang dihasilkan sebesar Rp. 10.748.000 setiap kolam pembesaran ikan nilem selama en am bulan pemeliharaan. Nilai B/C sebesar 1,24 menunjukkan bahwa usaha pembesaran ikan nilem layak untuk dikembangkan. Nilai B/C usaha tersebut lebih dari satu, artinya dari satu rupiah yang dikeluarkan akan mendapat penerimaan sebesar $\mathrm{Rp}$ 1,24. Titik balik modal akan tercapai bila BEP produksi ikan nilem mencapai 4596 ekor. Nilai Pay Back Periode sebesar 1,6 tahun yang berarti jangka waktu yang diperlukan untuk mendapatkan modal yang dikeluarkan adalah 1 tahun 7 bulan.

\section{KESIMPULAN DAN SARAN Kesimpulan}

Teknik pembesaran ikan nilem menggunakan kolam semi permanen, dimana pada bagian dinding kolam terbuat dari beton sedangkan pada bagian dasar kolam berupa tanah. Teknik pembesaran ikan nilem meliputi persiapan kolam, penyediaan air, pemberian pakan, monitoring kualitas air, pemasaran dan pemberantasan hama dan penyakit. Masalah pada pembesaran ikan nilem di BBPSIGN ialah adanya hama seperti ular, ikan betok, ikan gabus, ikan nila dan katak. Selain adanya hama, permasalahan lain dapat disebabkan karena adanya parasit Ichthyophthirius, sedangkan penyakit non infectious pada ikan nilem disebabkan karena perubahan kondisi lingkungan akibat cuaca yang sering berubah. Nilai $\mathrm{B} / \mathrm{C}$ ratio pada usaha pembesaran ikan nilem sebesar 1,24 ini menunjukan bahwa prospek pembesaran ikan nilem menguntungkan dan baik untuk dikembangkan selanjutnya.

\section{Saran}

Saran yang perlu diperhatikan di Balai Pengembangan dan Pemacuan Stok Ikan Gurame dan Nilem (BPPSIGN) 
Tasikmalaya, Jawa Barat sebaiknya alatalat yang digunakan untuk mengukur parameter kualitas air dan mikroskop yang ada di laboratorium ditingkatkan kuantitas dan kualitasnya serta dilakukan pergantian air dalam pembesraan ikan nilem agar dapat meminimalisir penyakit yang menyerang ikan nilem.

\section{DAFTAR PUSTAKA}

Komarudin, O., O. Preseno dan Z. I. Azwar. 1991. Infeksi parasit pada Benih Ikan Mas yang Dipelihara di Kolam dengan Sistem Aerasi. Buletin Penelitian Perikanan Darat 10 (1): 121-125.

Mulyasari, D.T. Soelistyowati, A.H. Kristanto, dan I.I. Kusmini. 2010. Karakteristik Genetik Enam Populasi Ikan Nilem (Osteochilus hasselti) di Jawa Barat. Jurnal Riset Akuakultur 5 (2): 175-182.

Simanjuntak, Armanto. 2010. Pengontrolan Suhu Air Pada Kolam Pendederan dan Pembenihan Ikan Nila Berbasis Arduino. Fakultas Teknik. Universitas Maritim Raja Ali Haji. 9 hal.

Subagja, J., R. Gustiano., dan Winarlin. 2007. Teknologi Reproduksi Ikan Nilem (Osteochilus hasselti C.V) : Pematangan Gonad, Penanganan Telur dan Penyediaan Calon Induk. Seminar Nasional Hari Pangan Sedunia XXVII. hal 187 - 194.

Wicaksono, P. 2005. Pengaruh Padat Tebar Terhadap Pertumbuhan dan Kelangsungan Hidup Ikan Nilem Osteochilus hasselti C.V. yang dipelihara dalam Keramba Jaring Apung di Waduk Cirata dengan Pakan Perifiton [Skripsi]. Institut Pertanian Bogor, Bogor.

Wijayanti G.E., Soeminto, Simanjuntak, S.B.I., Susatyp P., dan Pulungsari A.E. 1995. Studi Pendahuluan untuk peningkatan mutu benih ikan nilem (Osteochilus hasselti C.V.) melalui seleksi induk dan penetasan dalam akuarium.
Laporan Penelitian. Fakultas Biologi Unsoed. 